\title{
INVERTER JEMBATAN PENUH DENGAN RANGKAIAN RESONANSI PARALEL UNTUK FREKUENSI RENDAH BERBASIS IC SG3524
}

\author{
Mohammad Fadhil Koesputra*), Mochammad Facta, dan Iwan Setiawan \\ Departemen Teknik Elektro, Universitas Diponegoro \\ Jl. Prof. Sudharto, SH, Kampus UNDIP Tembalang, Semarang 50275, Indonesia \\ ${ }^{*}$ E-mail : fadhilkoes@gmail.com
}

\begin{abstract}
Abstrak
Photovoltaic merupakan sumber energi terbarukan yang banyak dikembangkan, akan tetapi keluaran dari photovoltaic masih berupa sumber listrik DC sehingga penggunaannya terbatas. Inverter full-bridge sebagai pengkonversi tegangan DC ke AC adalah salah satu solusi untuk mengatasi masalah tersebut. Pada penelitian ini, rangkaian inverter full-bridge dikontrol melalui pembangkit sinyal PWM analog IC SG3524. Rangkaian resonan paralel kemudian dirancang dan digunakan untuk memperbaiki bentuk gelombang keluaran dan meningkatkan level tegangan keluaran inverter. Pengujian dilakukan dengan variasi beban dan variasi frekuensi untuk melihat respon inverter full-bridge resonan paralel terhadap perubahan frekuensi dan beban. Beban yang digunakan berupa lampu pijar $15 \mathrm{~W}$, lampu pijar $25 \mathrm{~W}$, dan motor induksi satu fasa capacitor run. Hasil pengujian menunjukkan bahwa nilai tegangan output meningkat dari frekuensi $40 \mathrm{~Hz}$ ke 50 $\mathrm{Hz}$ sebelum kemudian mengalami penurunan dari frekuensi $50 \mathrm{~Hz}$ ke $60 \mathrm{~Hz}$. Frekuensi juga berpengaruh terhadap kecepatan putar motor dimana semakin besar nilai frekuensi maka akan semakin besar pula kecepatan putaran motor. Hasil pengujian dengan variasi pembebanan juga menunjukkan bahwa semakin besar beban yang terhubung, maka nilai tegangan output akan semakin rendah.
\end{abstract}

Kata kunci :inverter full-bridge, resonan paralel, SG3524, photovoltaic

\begin{abstract}
Solar Cell or photovoltaic is a renewable energy source that is most favourable to develop, but direct current output has made the application of PV is limited. The full-bridge inverter circuit as the direct to alternating current converter is one of the choices to withstand it. In this work, the full-bridge inverter circuit is controlled through an analog signal PWM generated by the IC SG3524. The parallel resonant circuit is designed and used to improve the output waveform and increase the output voltage of the inverter. Variation of load and frequency during the test is done to observe the fullbridge parallel resonant inverter performance. The load used is a $15 \mathrm{~W}$ incandescent lamp, $25 \mathrm{~W}$ incandescent lamp, and one phase induction motor capacitor run. The experimental results show that the output voltage value increased from the frequency of $40 \mathrm{~Hz}$ to $50 \mathrm{~Hz}$, but it decreased from frequency of $50 \mathrm{~Hz}$ to $60 \mathrm{~Hz}$. Frequency influences the motor rotation speed, as the frequency rise, the speed of motor rotation also increased. From the test with load variation, it is found that the greater the load connected, then the value of output voltage will be lower.
\end{abstract}

Keywords : full-bridge inverter, parallel resonant, SG3524, photovoltaic

\section{Pendahuluan}

Energi merupakan salah satu kebutuhan yang permintaannya senantiasa mengalami peningkatan. Hal ini memaksa kita untuk mencari solusi terhadap kebutuhan energi yang terus meningkat salah satunya yaitu pemanfaatan energi baru terbarukan. Photovoltaic (PV) merupakan sumber energi terbarukan yang populer dan banyak dikembangkan dengan beberapa keuntungan, seperti biaya operasional yang rendah, bebas biaya perawatan dan ramah lingkungan[1]. Akan tetapi pada prakteknya keluaran dari photovoltaic masih berupa sumber listrik DC sehingga penggunaannya terbatas. Maka dari itu diperlukan suatu alat yang bisa mengkonversi tegangan DC ke tegangan AC sehingga sumber photovoltaic bisa digunakan untuk menyuplai beban yang varatif.

Permasalahan ini dapat diatasi dengan menggunakan inverter 1 fasa. Inverter merupakan alat untuk mengubah dari tegangan DC menjadi $\mathrm{AC}[2]$. Salah satu jenisnya adalah inverter full-bridge. Inverter full-bridge memiliki keuntungan, yaitu dapat diaplikasikan untuk daya yang besar.

Selanjutnya nilai tegangan harus dinaikkan sehingga bisa dimanfaatkan untuk menyuplai beban yang bervariasi. Salah satu caranya yaitu dengan menggunakan 
transformator step up, namun transformator memiliki beberapa kekurangan salah satunya adalah adanya rugi tembaga, rugi arus eddy serta spike yang terjadi pada bentuk gelombang keluaran. Untuk mendapatkan bentuk gelombang sinusoidal dan memanfaatkan kemampuan penguatan tegangan pada rangkaian RLC maka digunakanlah konverter resonan[2][3].

Aplikasi resonan konverter telah dilakukan pada penelitian-penelitian sebelumnya, beberapa contohnya yakni berupa perancangan full-bridge inverter dengan resonan LC beban paralel[4] dan perancangan rangkaian resonan LCC frekuensi rendah[5]. Namun aplikasi sebelumnya masih menggunakan frekuensi tinggi dan menggunakan sumber daya dari penyearah, sehingga belum diuji untuk aplikasi photovoltaic dan tidak sesuai untuk catu daya beban yang bervariasi.

Dari beberapa penelitian yang telah dilakukan, akan dilakukan penelitian yang menggunakan topologi inverter full-bridge resonan paralel frekuensi rendah dengan IC SG3524 sebagai pembangkit sinyal PWM. Pengujian dilakukan dengan pengaturan frekuensi pada beban resistif lampu pijar $(15 \mathrm{~W}, 25 \mathrm{~W})$ dan beban motor induksi 1 fasa capacitor run.

\section{Metode}

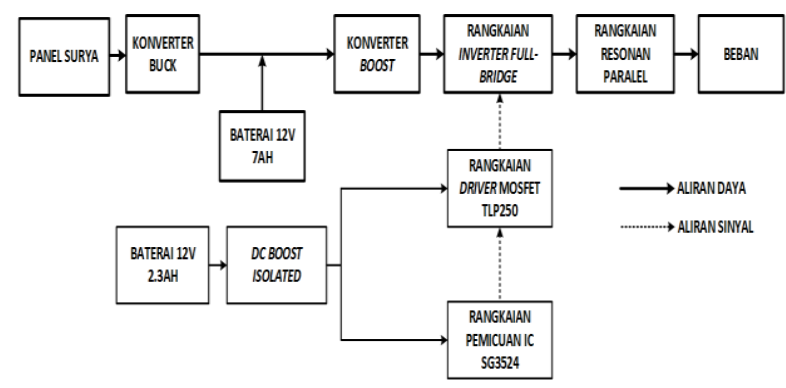

Gambar 1. Blok diagram perancangan

Gambar 1. merupakan blok diagram perancangan sistem inverter full-bridge resonan paralel. Perancangan ini terdiri 2 sistem utama yaitu rangkaian daya dan rangkaian kontrol. Pada rangkaian kontrol terdapat baterai $12 \mathrm{~V} \mathrm{2,3}$ Ah sebagai sumber, rangkaian DC Boost Isolated, rangkaian pemicuan IC SG3524, dan rangkaian driver MOSFET TLP250. Pada rangkaian daya terdapat panel surya, rangkaian buck converter, baterai $12 \mathrm{~V} 7$ Ah sebagai sumber, boost converter, inverter full-bridge, dan rangkaian resonan paralel.

\subsection{Modul Panel Surya}

Modul panel surya yang digunakan adalah tipe monocrystalline. Modul ini dirancang dengan sumber cahaya dihadapkan langsung menghadap panel surya, sehingga cahaya dan panel surya membentuk sudut $90^{\circ}[6]$.
Penelitian dilakukan dalam kondisi panel surya yang berada dalam kotak yang tertutup dengan sumber penyinaran dari lampu halogen 50 watt 220 volt yang dipasang secara paralel. Modul panel surya yang digunakan dalam percobaan dengan spesifikasi sebagai berikut.

Tabel 1. Panel surya pada 1000 watt $/ \mathrm{m}^{2}$ temperatur $25^{\circ} \mathrm{C}$

\begin{tabular}{ll}
\hline Spesifikasi panel surya & Nilai \\
\hline Daya maksimum (W) & 10 Watt \\
Tegangan optimal (Vmp) & 18 Volt \\
Arus optimal (Imp) & 0.56 Ampere \\
Tegangan hubung buka(Voc) & 21.7 Volt \\
Arus hubung singkat (Isc) & 0.59 Ampere \\
Suhu operasi & $-40^{\circ} \mathrm{C}$ to $+85^{\circ} \mathrm{C}$ \\
\hline
\end{tabular}

\subsection{Baterai $12 \mathrm{~V}$}

Baterai akumulator yang digunakan pada penelitian ini masing-masing memiliki kapasitas sebesar 7 Ah dan 2,3 Ah. Baterai 7 Ah beroperasi secara floating dengan photovoltaic sebagai sumber rangkaian daya, dan aterai 2,3 Ah digunakan sebagai sumber untuk rangkaian kontrol.

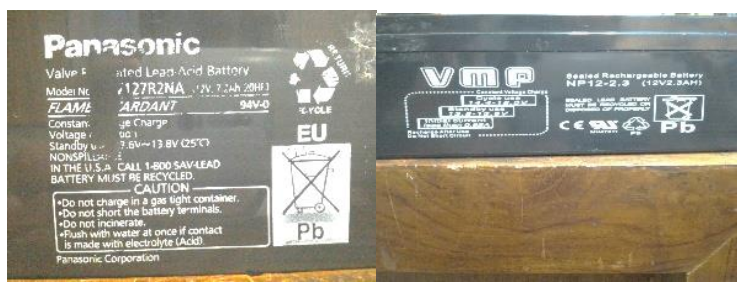

Gambar 3. Baterai 12V

\subsection{Blok Buck Converter}

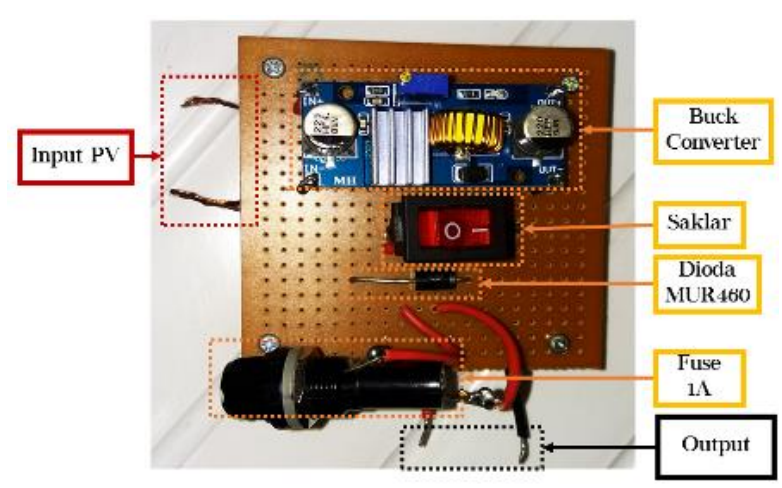

Gambar 2. Rangkaian blok buck converter

Rangkaian blok buck konverter menggunakan sumber dari box panel surya dengan tegangan sebesar 20V. Blok buck konverter berfungsi menurunkan tegangan panel surya menjadi sebesar 12,5-13 V sehingga baterai dapat bekerja dengan panel surya dalam kondisi floating. Rangkaian blok buck konverter ini terdiri dari modul buck converter yang dilengkapi dengan dioda tipe MUR460 agar tidak terjadi 
tegangan balik dan pengaman fuse 1A untuk mengamankan panel surya.

Tabel 2. Parameter Modul Buck Konverter

\begin{tabular}{ll}
\hline Parameter & Nilai Besaran \\
\hline Input Voltage dari panel surya & $20 \mathrm{~V}$ \\
Output Voltage & $12-14 \mathrm{~V}$ \\
Diode MUR460 & $4 \mathrm{~A}, 200-600 \mathrm{~V}$ \\
Modul Buck converter & $5 \mathrm{~A}, 5-35 \mathrm{~V}$ \\
Fuse & $1 \mathrm{~A}$ \\
\hline
\end{tabular}

\subsection{Modul Boost Converter}

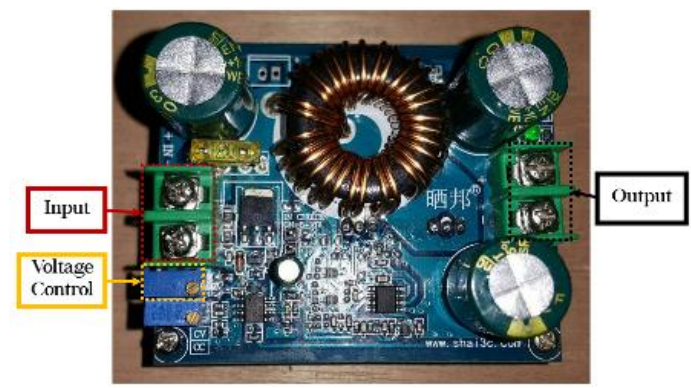

Gambar 3. Modul boost converter

Boost converter pada skema perancangan penelitian digunakan untuk menaikkan level tegangan DC dari baterai. Boost yang digunakan memiliki range input 9-60 $\mathrm{Vdc}$ dan range output $12-80 \mathrm{Vdc}$ dengan arus maksimal 12A. Input boost berasal dari baterai, nilai tegangan keluaran boost di-set pada tegangan 45-50V dengan input baterai pada kisaran 12-12,5V. Kemudian output boost masuk ke blok rangkaian inverter full-bridge. Pada boost juga telah dilengkapi fuse $20 \mathrm{~A}$ pada input sebagai proteksi short circuit dan over current.

Tabel 3. Parameter Modul Buck Konverter

\begin{tabular}{ll}
\hline Parameter & Nilai Besaran \\
\hline Input Voltage & $9-60 \mathrm{~V}$ \\
Output Voltage & $12-80 \mathrm{~V}$ \\
Input Current Max & $16 \mathrm{~A}$ \\
Output Current Max & $12 \mathrm{~A}$ \\
Conversion Efficiency & $95 \%$ \\
Operating Frequency & $150 \mathrm{kHz}$ \\
Operating Temperature & -40 to $^{\circ} \mathrm{C} \mathrm{C}^{\mathrm{C}}$ \\
\hline
\end{tabular}

\subsection{Rangkaian DC Boost Isolated}

Rangkaian DC boost isolated berfungsi untuk membuat ground yang terpisah dari satu sumber DC[7], dikarenakan butuh sumber DC dengan ground terpisah untuk menyuplai IC SG3524 dan keempat IC TLP250 yang digunakan. DC Boost Isolated yang digunakan adalah tipe MORNSUN B1215S-2W.

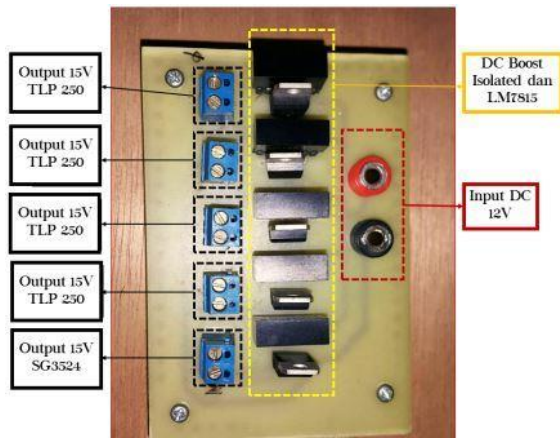

Gambar 4. Rangkaian DC boost isolated

Tabel 4. Spesifikasi DC Boost Isolated MORNSUN B1215S

\begin{tabular}{ll}
\hline Parameter & Nilai Besaran \\
\hline Input Voltage & $12 \mathrm{~V}$ \\
Output Voltage & $15 \mathrm{~V}$ \\
Supply voltage & $10-35 \mathrm{~V}$ \\
Output Current Operating & $14-133 \mathrm{~mA}$ \\
Temperatur & -400 until $850 \mathrm{C}$ \\
\hline
\end{tabular}

\subsection{Rangkaian Daya}

\subsubsection{Inverter Full-Bridge}

Rangkaian inverter yang dirancang adalah jenis full-bridge dengan 4 MOSFET sebagai piranti pensaklaran

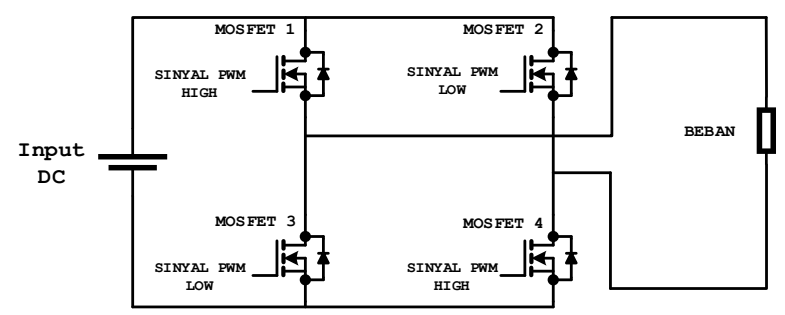

Gambar 5. Rangkaian inverter full-bridge

Parameter penting yang harus diperhatikan dalam pemilihan komponen MOSFET diantaranya yaitu nilai dari tegangan dan arus kerja MOSFET. Diketahui bahwa nilai tegangan yang bekerja pada MOSFET yaitu 50v, dan nilai arusnya 2,1A. Pada penelitian ini digunakan MOSFET tipe IRFP460 sebagai piranti pensaklaran karena spesifikasinya telah memadai.

\subsubsection{Rangkaian Resonan Parale}

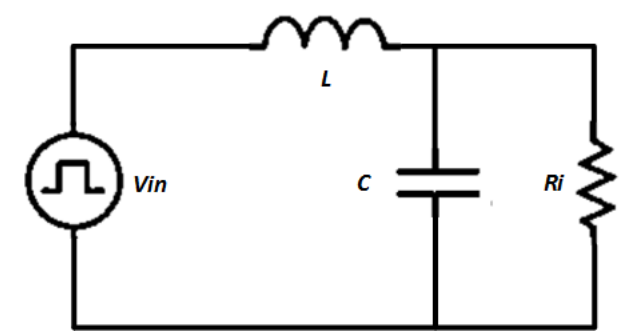

Gambar 6. Rangkaian resonan paralel 
Rangkaian resonan paralel terdiri atas rangkaian $\mathrm{L}$ dan $\mathrm{C}$ yang terhubung secara seri dan beban yang terhubung paralel dengan $\mathrm{C}$.

Ditentukan frekuensi resonansi yang diinginkan sebesar 50 Hz. Pemilihan frekuensi resonansi sebesar $50 \mathrm{~Hz}$ karena hampir seluruh beban listrik AC yang digunakan di Indonesia bekerja pada frekuensi tersebut. Nilai kapasitor yang dipilih sebesar $26,8 \mu \mathrm{F}$, karena nilai ini masih bisa dirangkai dengan komponen yang tersedia dipasaran. Dengan mengetahui nilai $\mathrm{C}$ dan frekuensi resonansi, dapat dihitung nilai induktansi yang dibutuhkan dengan turunan dari persamaan (1)[8]

$$
\begin{aligned}
& f_{o}=\frac{1}{2 \pi \sqrt{L C}} \\
& L=\frac{1}{2 \pi f_{0}^{2} C} \\
& L=\frac{1}{(2 \pi \times 50)^{2} 26,8 \times 10^{-6}}=378 \mathrm{mH}
\end{aligned}
$$

Kita juga dapat menghitung nilai faktor kualitas dari rangkaian resonan dengan contoh pada beban lampu pijar $15 \mathrm{~W}$ dengan resistansi $289,25 \Omega$.

$$
\begin{aligned}
Q_{L} & =\frac{R_{i}}{\sqrt{L / C}} \\
Q_{L} & =\frac{289,25}{\sqrt{378 / 26,8}}=2,435
\end{aligned}
$$

Dari perhitungan yang dilakukan diketahui bahwa nilai faktor kualitas pada beban lampu pijar $15 \mathrm{~W}$ yaitu 2,435 . Selain itu kita juga dapat melihat grafik respon frekuensi rangkaian resonan pada beban lampu pijar $15 \mathrm{~W}$ dengan bantuan software Microsoft Excel, maka didapatkan grafik pada gambar 7 .

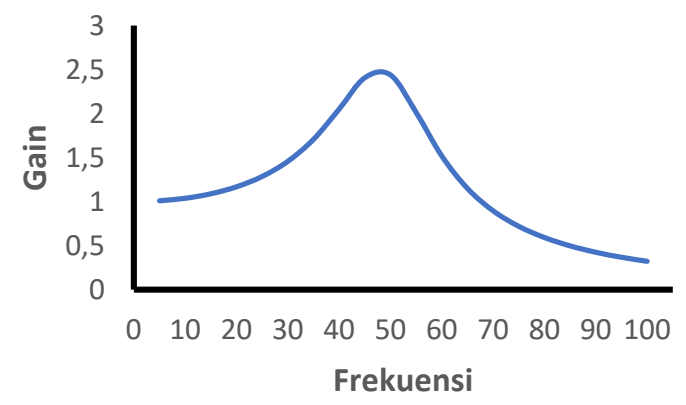

Gambar 7. Grafik pengaruh frekuensi terhadap gain

Dari Gambar 7, dapat dilihat bahwasannya tegangan keluaran mengalami kenaikan seiring dengan bertambahnya frekuensi hingga mencapai titk maksimumnya pada frekuensi resonansi $50 \mathrm{~Hz}$, apabila frekuensi dinaikkan melebihi frekuensi resonansi, maka tegangan keluaran akan berangsur-angsur mengalami penurunan.

\subsection{Rangkaian Kontrol Pembangkit Sinyal PWM IC SG3524}

Rangkaian kontrol IC SG3524 digunakan untuk menghasilkan sinyal PWM (Pulse Width Modulation). Rangkaian kontrol IC SG3524 dapat mengatur frekuensi dan duty cycle dari gelombang PWM. Nilai frekuensi osilasi pada rangkaian kontrol IC SG3524 diatur oleh dua komponen yang dihubungkan dengan pin 6 dan 7. Pin 6 IC SG3524 adalah Resistor Timer $\left(\mathrm{R}_{\mathrm{T}}\right)$ dan pin 7 IC SG3524 adalah Capacitor Timer $\left(\mathrm{C}_{\mathrm{T}}\right)$. Persamaan untuk mencari frekuensi kerja sesuai pada datasheet IC SG3524 dituliskan oleh persamaan (4)[9] berikut :

$f=\frac{1,3}{R_{T} C_{T}}$

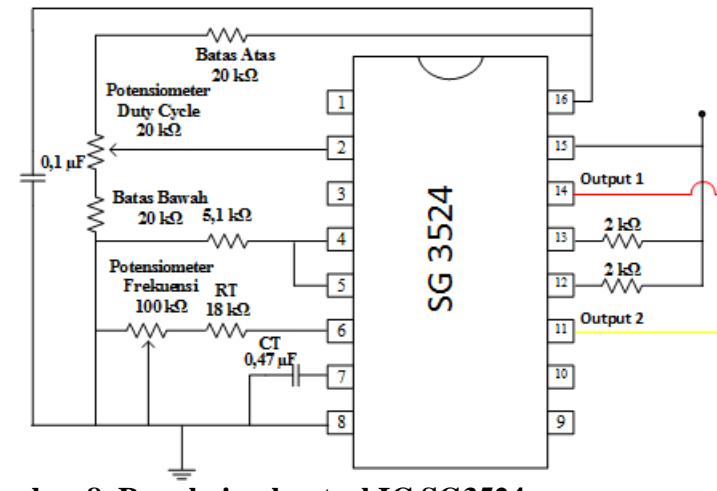

Gambar 8. Rangkaian kontrol IC SG3524

Salah satu fitur IC SG3524 adalah memiliki 2 mode gelombang keluaran PWM, salah satunya yaitu konfigurasi push-pull yang menghasilkan output gelombang PWM yang saling berkebalikan antara kedua kaki outputnya. Hal tersebut menjadi fitur yang tepat untuk digunakan sebagai pemicuan MOSFET pada inverter full-bridge. Rangkaian pemicuan direncanankan mampu beroperasi pada range frekuensi $23 \mathrm{~Hz}-153 \mathrm{~Hz}$.

\subsection{Rangkaian MOSFET Driver IC TLP250}

Rangkaian MOSFET driver menggunakan IC TLP250. Rangkaian TLP250 digunakan untuk mengisolasi dan menguatkan sinyal PWM[10]. Ground antara TLP250 dengan IC SG3524 terpisah sebagai fungsi isolasi antara rangkaian kontrol dan daya.

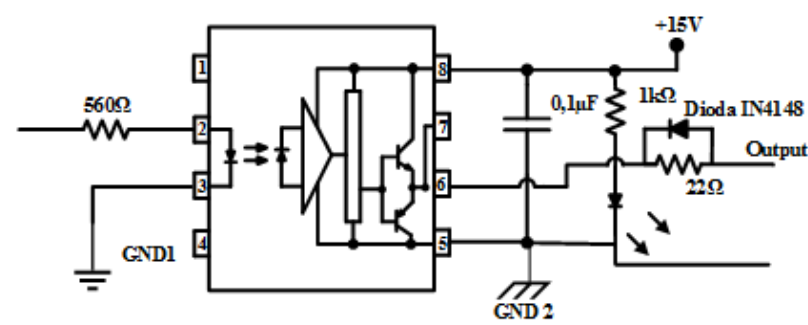

Gambar 9. Rangkaian MOSFET driver TLP250 
Setelah mendapat masukan berupa gelombang kotak keluaran dari IC SG3524, rangkaian MOSFET driver langsung meneruskan gelombang pemicuan tersebut ke rangkaian daya.

\section{Hasil dan Analisa}

3.1. Pengujian Gelombang Keluaran Rangkaian Kontrol

\subsubsection{Pengujian Gelombang Keluaran IC SG3524}

Pengujian rangkaian kontrol pembangkit sinyal PWM dengan IC SG3524 bertujuan untuk mengetahui karakteristik gelombang pulsa keluaran IC SG3524 dan memastikan bahwa gelombang tegangan keluaran dari IC SG3524 telah sesuai dengan perancangan. Pengukuran dilakukan pada kaki 11 dan 14 yang akan digunakan sebagai masukan pemicuan gate MOSFET. Pengujian dilakukan pada kaki 11 dan 14 sebagai keluaran dari IC SG3524.

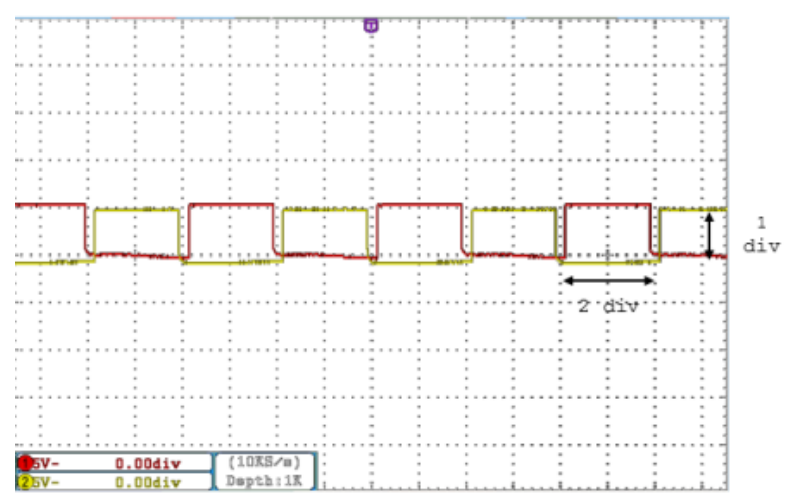

Gambar 10. Gelombang keluaran IC SG3524

IC SG3524 beroperasi dalam mode push-pull dimana gelombang pemicuan antara kaki 11 dan 14 memiliki waktu pemicuan yang berkebalikan (inverting) dengan range frekuensi $12 \mathrm{~Hz}-75 \mathrm{~Hz}$. Hasil yang didapat telah mendekati perancangan. Adanya perbedaan antara hasil pengujian dan perancangan dikarenakan adanya efek parasitik pada rangkaian.

\subsubsection{Pengujian Gelombang Keluaran MOSFET Driver TLP250}

Pengujian pada rangkaian ini dilakukan untuk mengetahui dan memastikan gelombang tegangan keluaran dari MOSFET driver TLP250 telah sesuai dengan perancangan dan dapat digunakan untuk pemicuan MOSFET.

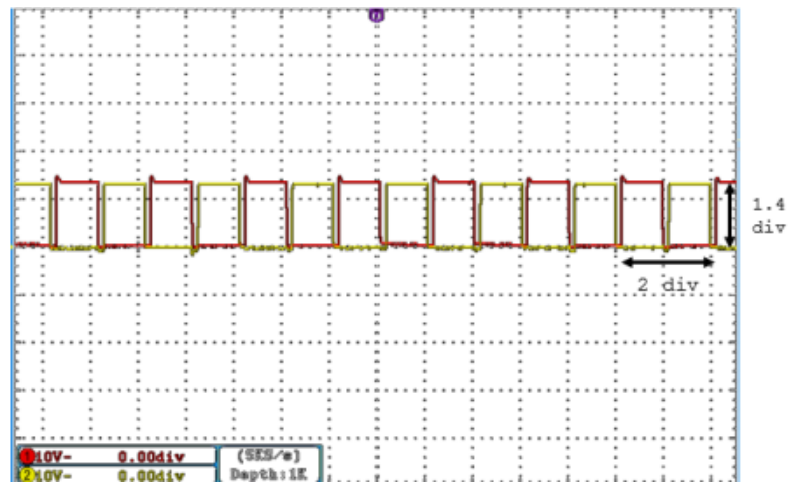

Gambar 11. Gelombang keluaran driver MOSFET TLP250

Hasil pengujian gelombang keluaran dari MOSFET driver TLP250 telah sesuai dengan perancangan dan dapat digunakan untuk memicu MOSFET.

\subsection{Pengujian Rangkaian Inverter Full-Bridge}

Pengujian ini dilakukan untuk mengetahui bentuk gelombang tegangan keluaran dari rangkaian inverter fullbridge tanpa resonan. Pengujian dilakukan dalam kondisi tanpa beban.

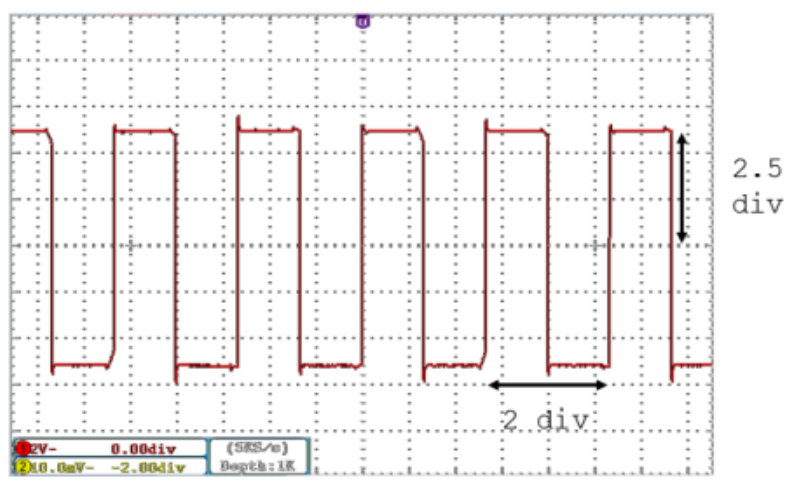

Gambar 12. Gelombang tegangan keluaran inverter fullbridge tanpa beban

Dari Gambar 12 diketahui bahwa gelombang tegangan keluaran dari inverter full-bridge tanpa resonan masih dalam bentuk kotak (square wave), hal ini disebabkan karena pemicuan yang digunakan pada MOSFET masih menggunakan pemicuan analog yang berupa PWM (Pulse Width Modulation).

\subsection{Pengujian Rangkaian Inverter Full-Bridge Resonan Paralel}

Pengujian ini dilakukan untuk mengetahui bentuk gelombang tegangan keluaran dari rangkaian inverter fullbridge dengan resonan paralel dalam kondisi tanpa beban. 


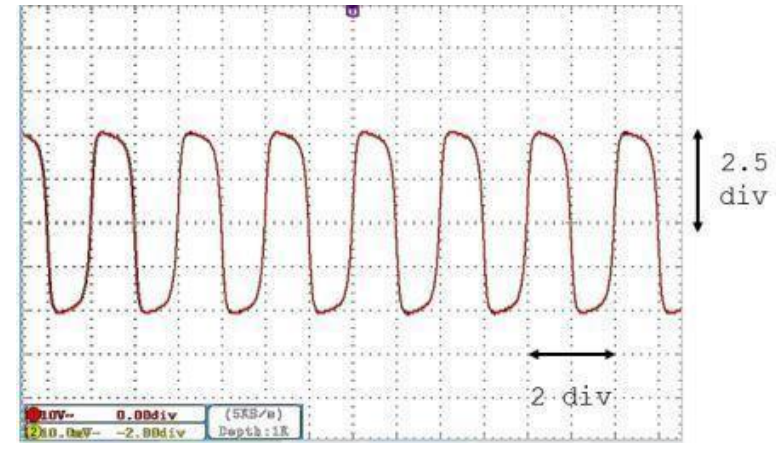

Gambar 13. Gelombang tegangan keluaran inverter fullbridge resonan paralel tanpa beban

Dari gambar 13 diketahui bahwa gelombang tegangan keluaran dari inverter full-bridge resonan telah mendekati bentuk gelombang sinusoidal meskipun masih belum sempurna. Selain itu terjadi penguatan tegangan pada sisi keluaran inverter full-bridge resonan paralel, dimana tegangan pada input sebesar $50 \mathrm{v}$, dan pada output tegangan $\mathrm{V}_{\text {rms }} 176,77 \mathrm{v}$.

\subsubsection{Pengujian Beban Lampu $15 W(289,25 \Omega)$}

Pengujian ini dilakukan untuk mengetahui bentuk gelombang tegangan keluaran dari rangkaian inverter fullbridge dengan resonan paralel dalam kondisi beban lampu pijar $15 \mathrm{~W}$.

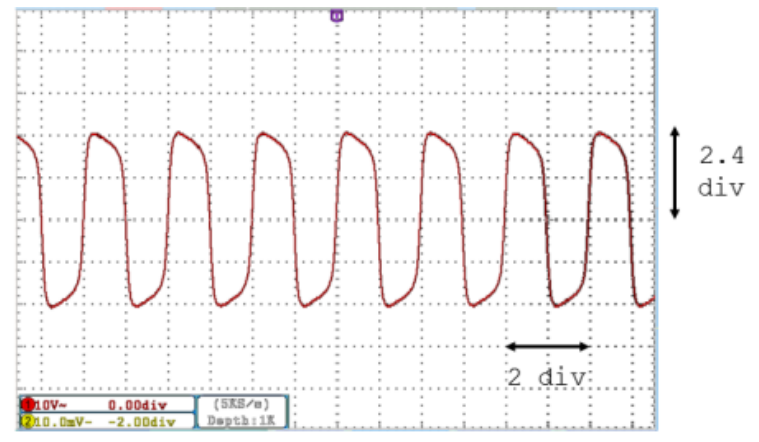

Gambar 14. Gelombang tegangan keluaran inverter fullbridge resonan paralel beban lampu pijar $15 \mathrm{~W}$

Dari Gambar 14 diketahui bahwa gelombang tegangan keluaran dari inverter full-bridge resonan telah mendekati bentuk gelombang sinusoidal meskipun masih belum sempurna. Selanjutnya dilakukan pengujian dengan variasi frekuensi untuk mengetahui pengaruh frekuensi terhadap respon tegangan dari inverter full-bridge resonan paralel pada kondisi beban lampu pijar $15 \mathrm{~W}$ sehingga didapatkan tabel 5 .

Berdasarkan tabel 5 dapat diketahui bahwa nilai tegangan output meningkat dari frekuensi $40 \mathrm{~Hz}$ ke $50 \mathrm{~Hz}$ sebelum kemudian mengalami penurunan dari frekuensi $50 \mathrm{~Hz}$ ke $60 \mathrm{~Hz}$. Hal ini telah sesuai dengan teori yang ada, karena nilai penguatan tegangan paling tinggi terjadi ketika nilai frekuensi sama dengan frekuensi resonansi.

Tabel 5. Hasil pengujian variasi frekuensi lampu pijar 15W duty cycle $\mathbf{4 5 \%}$

\begin{tabular}{cccccc}
\hline $\mathbf{f}(\mathrm{Hz})$ & $\operatorname{Vin}\left(\mathbf{V}_{\mathbf{D C}}\right)$ & lin $(\mathbf{A})$ & Vout $\left(\mathbf{V}_{\mathrm{AC}}\right)$ & lout $(\mathbf{A})$ & cosphi \\
\hline 40 & 48.3 & 0.51 & 138 & 0.06 & 1 \\
45 & 47.78 & 0.6 & 153 & 0.07 & 1 \\
50 & 46.6 & 0.94 & 174 & 0.07 & 1 \\
55 & 42.1 & 1.01 & 168 & 0.07 & 1 \\
60 & 37.9 & 1.15 & 158 & 0.07 & 1 \\
\hline
\end{tabular}

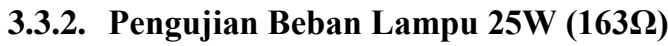

Pengujian ini dilakukan untuk mengetahui bentuk gelombang tegangan keluaran dari rangkaian inverter fullbridge dengan resonan paralel dalam kondisi beban lampu pijar $25 \mathrm{~W}$.

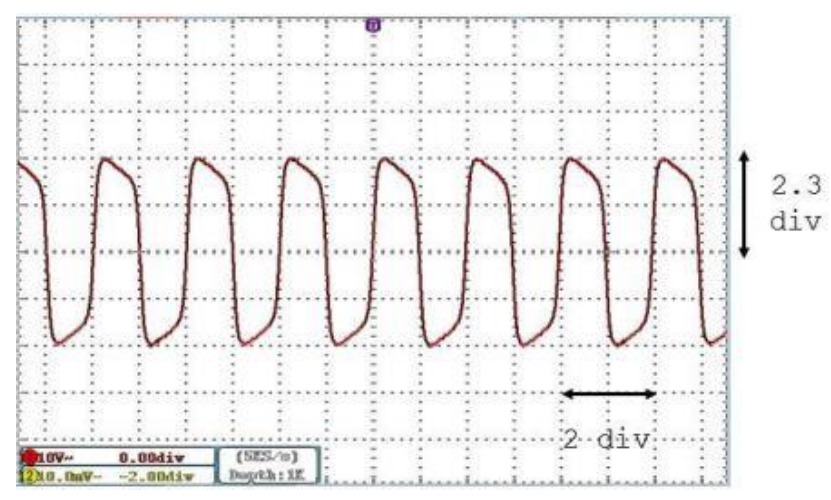

Gambar 15. Gelombang tegangan keluaran inverter fullbridge resonan paralel beban lampu pijar $25 \mathrm{~W}$

Dari Gambar 15 diketahui bahwa gelombang tegangan keluaran dari inverter full-bridge resonan telah mendekati bentuk gelombang sinusoidal meskipun masih belum sempurna. Selanjutnya dilakukan pengujian dengan variasi frekuensi untuk mengetahui pengaruh frekuensi terhadap respon tegangan dari inverter full-bridge resonan paralel pada kondisi beban lampu pijar 25W sehingga didapatkan tabel 6 .

Tabel 6. Hasil pengujian variasi frekuensi lampu pijar $25 \mathrm{~W}$ duty cycle $\mathbf{4 5 \%}$

\begin{tabular}{cccccc}
\hline $\mathbf{f}(\mathrm{Hz})$ & Vin $\left(\mathbf{V}_{\mathbf{D C}}\right)$ & lin $(\mathbf{A})$ & Vout $\left(\mathrm{V}_{\mathbf{A C}}\right)$ & lout $(\mathbf{A})$ & cosphi \\
\hline 40 & 48,9 & 0,58 & 134 & 0,082 & 1 \\
45 & 48,5 & 0,7 & 148 & 0,086 & 1 \\
50 & 47,9 & 0,9 & 163,9 & 0,09 & 1 \\
55 & 45,3 & 1,54 & 162,6 & 0,09 & 1 \\
60 & 42 & 1,16 & 153,7 & 0,09 & 1 \\
\hline
\end{tabular}

Berdasarkan tabel 6 dapat diketahui bahwa nilai tegangan output meningkat dari frekuensi $40 \mathrm{~Hz}$ ke $50 \mathrm{~Hz}$ sebelum kemudian mengalami penurunan dari frekuensi $50 \mathrm{~Hz}$ ke $60 \mathrm{~Hz}$. Hal ini telah sesuai dengan teori yang ada, karena 
nilai penguatan tegangan paling tinggi terjadi ketika nilai frekuensi sama dengan frekuensi resonansi.

\subsubsection{Pengujian Beban Motor Induksi 1 Fasa Capacitor-Run}

Pengujian ini dilakukan untuk mengetahui bentuk gelombang tegangan keluaran dari rangkaian inverter fullbridge dengan resonan paralel dalam kondisi beban motor induksi 1 fasa capacitor run.

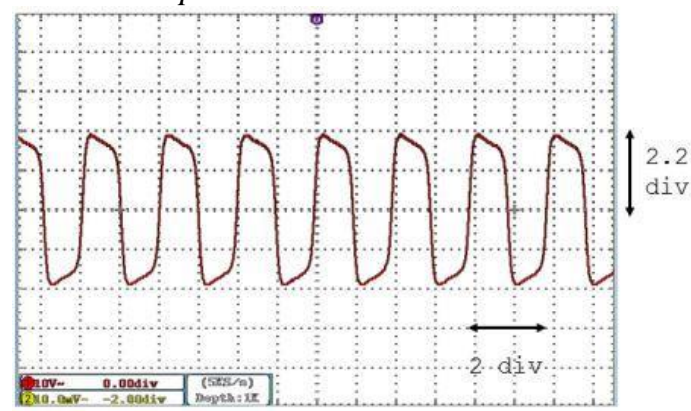

Gambar 16. Gelombang tegangan keluaran inverter fullbridge resonan paralel beban motor.

Dari Gambar 16 diketahui bahwa gelombang tegangan keluaran dari inverter full-bridge resonan telah mendekati bentuk gelombang sinusoidal meskipun masih belum sempurna. Selanjutnya dilakukan pengujian dengan variasi frekuensi untuk mengetahui pengaruh frekuensi terhadap respon tegangan dari inverter full-bridge resonan paralel pada kondisi beban motor induksi 1 fasa capacitor-run sehingga didapatkan tabel 7 .

Tabel 7. Hasil pengujian variasi frekuensi motor induksi 1 fasa duty cycle $45 \%$

\begin{tabular}{ccccccc}
\hline $\begin{array}{c}\mathbf{f} \\
(\mathbf{H z})\end{array}$ & $\begin{array}{c}\text { Vin } \\
\left(\mathbf{V}_{\mathbf{D C}}\right)\end{array}$ & $\begin{array}{c}\text { lin } \\
(\mathbf{A})\end{array}$ & $\begin{array}{c}\text { Vout } \\
\left(\mathbf{V}_{\mathbf{A C}}\right)\end{array}$ & $\begin{array}{c}\text { lout } \\
(\mathbf{A})\end{array}$ & $\begin{array}{c}\text { cosph } \\
\mathbf{i}\end{array}$ & $\begin{array}{c}\mathbf{n} \\
(\mathbf{r p m})\end{array}$ \\
\hline 40 & 48,7 & 0,58 & 132 & 0,096 & 0,83 & 1190 \\
45 & 48,3 & 0,7 & 147 & 0,099 & 0,91 & 1344 \\
50 & 47,6 & 0,9 & 157 & 0,113 & 0,996 & 1500 \\
55 & 45,8 & 1,06 & 155,25 & 0,114 & 0,95 & 1592 \\
60 & 43 & 1,09 & 142,37 & 0,125 & 0,89 & 1744 \\
\hline
\end{tabular}

Berdasarkan tabel 7 dapat diketahui bahwa nilai tegangan output meningkat dari frekuensi $40 \mathrm{~Hz}$ ke $50 \mathrm{~Hz}$ sebelum kemudian mengalami penurunan dari frekuensi $50 \mathrm{~Hz}$ ke $60 \mathrm{~Hz}$. Hal ini telah sesuai dengan teori yang ada, karena nilai penguatan tegangan paling tinggi terjadi ketika nilai frekuensi sama dengan frekuensi resonansi. Selain itu didapati juga bahwa nilai kecepatan motor mengalami peningkatan dari frekuensi $40 \mathrm{~Hz}$ sampai $60 \mathrm{~Hz}$. Hal ini juga telah sesuai dengan teori dimana frekuensi berbanding lurus dengan kecepatan putar motor.

\subsubsection{Perbandingan Tegangan Keluaran pada Variasi Pembebanan}

Dari pengujian rangkaian inverter full-bridge resonan paralel dengan berbagai variasi pembebanan, didapatkan hasil yang tertera pada tabel 8 berikut ini
Tabel 8. Hasil pengujian variasi frekuensi dan pembebanan duty cycle $\mathbf{4 5 \%}$

\begin{tabular}{cccc}
\hline $\mathbf{f}(\mathbf{H z})$ & Lampu pijar 15W & $\begin{array}{c}\text { Vout (V) } \\
\text { Lampu Pijar 25W }\end{array}$ & Motor Induksi 1 Fasa \\
\hline 40 & 138 & 134 & 132 \\
45 & 153 & 148 & 147 \\
50 & 174 & 163,9 & 157 \\
55 & 168 & 162,6 & 155,25 \\
60 & 158 & 153,7 & 142,37 \\
\hline
\end{tabular}

Berdasarkan data hasil pengujian pada Tabel 8 dapat dibuat grafik perbandingan antara frekuensi dengan tegangan keluaran seperti pada Gambar 16.

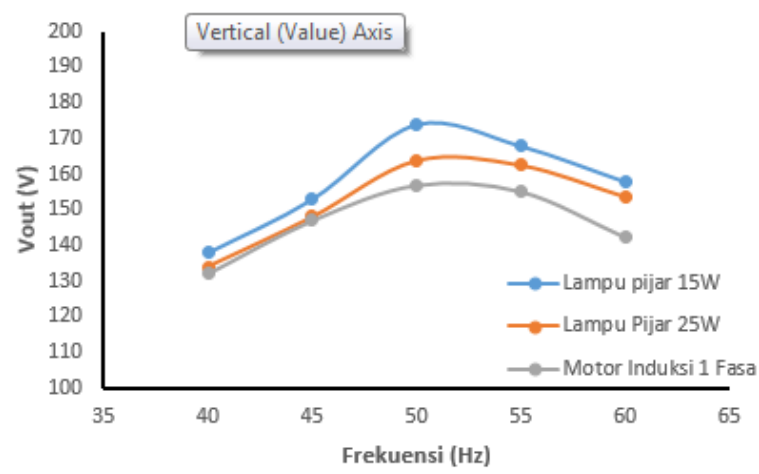

Gambar 16. Gelombang hubungan frekuensi dan tegangan keluaran

Dari tabel 8 dan gambar 16 dapat diambil kesimpulan bahwa beban mempengaruhi tegangan output dari inverter full-bridge resonan paralel. Semakin besar beban yang terhubung, maka nilai tegangan output akan semakin rendah. Hal ini telah sesuai dengan teori yang ada, apabila beban yang terhubung pada rangkaian resonan semakin besar maka faktor kualitas dari rangkaian resonan akan menurun, sehingga nilai penguatan tegangan pada rangkaian resonan juga mengalami penurunan.

\section{Kesimpulan}

Inverter jenis full-bridge resonan paralel sudah berhasil dibuat. Dari pengujian yang dilakukan dapat diketahui bahwa penggunaan rangkaian resonan paralel mampu memperbaiki atau memperhalus bentuk gelombang dan meningkatkan level tegangan keluaran. Berdasarkan pengujian yang telah dilakukan pada variasi frekuensi, diketahui bahwa frekuensi mempengaruhi tegangan output dari inverter full-bridge resonan paralel. Nilai tegangan output meningkat dari frekuensi $40 \mathrm{~Hz}$ ke $50 \mathrm{~Hz}$ sebelum kemudian mengalami penurunan dari frekuensi $50 \mathrm{~Hz}$ ke $60 \mathrm{~Hz}$. Berdasarkan teori yang ada, nilai penguatan tegangan paling tinggi terjadi ketika nilai frekuensi sama dengan frekuensi resonansi. Hal ini telah sesuai dengan hasil yang didapat dari pengujian karena frekuensi resonansi dari rangkaian resonan yang dirancang adalah 50 Hz. Frekuensi juga berpengaruh terhadap kecepatan putar 
motor dimana semakin besar nilai frekuensi maka akan semakin besar pula kecepatan putaran motor. Berdasarkan pengujian yang telah dilakukan dalam variasi pembebanan, dapat diambil kesimpulan bahwa beban mempengaruhi tegangan output dari inverter full-bridge resonan paralel. Semakin besar beban yang terhubung, maka nilai tegangan output akan semakin rendah. Berdasarkan teori yang ada, apabila beban yang terhubung pada rangkaian resonan semakin besar maka faktor kualitas dari rangkaian resonan akan menurun, sehingga nilai penguatan tegangan pada rangkaian resonan juga mengalami penurunan. Hal ini telah sesuai dengan hasil yang didapat dari pengujian karena seiring dengan meningkatnya beban yang terhubung, nilai tegangan output juga mengalami penurunan.

\section{Referensi}

[1]. M. Suyanto, "Pemanfaatan Solar Cell sebagai Pembangkit Listrik Terbarukan," J. Tek., vol. 27, no. ISSN 1410-8216, 2014.

[2]. M. H. Rashid, Power Electronics Handbook: Circuits, Devices, and Application, Second. San Diego, California: Elsevier Inc, 2007.
[3]. R. W. Erickson and D. Maksimovic, Fundamentals of Power Electronics, 2nd ed. New York: Kluwer Academic, 2004.

[4]. T. Miftah Isnain, M. Facta, and Karnoto, “Analisis Kerja Inverter Jembatan Penuh dengan Rangkaian Pasif LC Beban Paralel," TRANSIENT, vol. 4, no. 1, p. 147, 2015.

[5]. R. Zein W N, M. Facta, and Karnoto, "Analisis Penguatan Tegangan Rangkaian Resonan LCC pada frekuensi 30$100 \mathrm{~Hz}, ”$ TRANSMISI, vol. 2, no. 17, pp. 1-7, 2015.

[6]. M. Prasetyawan, A. Nugroho, and M. Facta, "Modul Praktikum Penyinaran Sebagian dan Penuh pada Photovoltaic Jenis Monocristalline," TRANSIENT, vol. 3, no. 3, 2014

[7]. MORNSUN, "B1512S-2W Datasheet," 2008.

[8]. M. K. Kazimierczuk and D. Czarkowski, Resonant Power Converters, 2nd ed. New Jersey: John Wiley \& Sons, INC., 2011.

[9]. Texas Instrument, "SG3524, SG2524 Datasheet," Dallas, Texas, 2003.

[10]. TOSHIBA, "TLP250 Datasheet," 2017.

[11]. M. Amjad, Z. Salam, M. Facta, and K. Ishaque, "Design and Development of a High-Voltage Transformer-less Power Supply for Ozone Generators Based on a Voltagefed Full Bridge Resonant Inverter," J. Power Electron., vol. 12, no. 3, pp. 387-398, 2012.

[12]. D. V. Nugraha, M. Facta, and A. Warsito, "Analisis Inverter Dual Resonan sebagai Catu Daya Lampu LED," Transient, vol. 2, no. 4, pp. 1-8, 2013. 